\title{
Egy pénzügyes közgazda gondolatai A közgazdaságtan megváltásáról
}

\author{
Redeeming Economics: \\ A Financial Expert's Views
}

Összefoglalás

A tanulmány szerzôje J. Mueller könyve alapján úgy véli, hogy a közgazdaságtan alapvetô reformra szorul. A klasszikus és a neoklasszikus közgazdaságtan elôtt létezô skolasztikus közgazdasági gondolkodáshoz kell visszatérni, és az akkori eszmékból merítve, a modern közgazdaságtant neoskolasztikus elméletté alakítani. Egy társadalomban nemcsak piaci típusú kapcsolatok léteznek, viszonyunk a társadalom tagjaihoz a szereteten alapul, amelynek mértéke különböző a rokonainkhoz, illetve a társadalom többi tagjához. Így rokonaink termékeket és szolgáltatásokat nem áruként, hanem ajándékba kapnak tôlünk, melynek messzire ható konzekvenciái vannak. A gazdaság és társadalom alapja a család, gyermekeinkre mint idôs korunkra befektetést jelentô humán tôkére kell tekintenünk. A pénznek a társadalmat kell szolgálnia, és nem fordítva. A vallási háttér a demokrácia és a szabadpiaci gazdaság számára egyaránt fontos a modern korban is.

Journal of Economic Literature (JEL) kódok: H55, B1, E5, Y3

Kulcsszavak: gazdaság elmélettörténete, áru és ajándék, családalapú gazdaság, hit és gazdaság

Prof. Dr. Botos Katalin, professor emerita, Szegedi Tudományegyetem

(evmkabor@gmail.com). 
Botos Katalin: Egy pénzügyes közgazda gondolatai A közgazdaságtan megváltásáról

Summary

Based on a book by John D. Mueller, the author analyses the need for a reform in economic thinking. We should return to the scholastic economic thought that preceded the classical and the neo-classical theories, and draw inspiration from those ideas, converting modern economic theory into a neo-scholastic one. A society is not merely built on market-type relations. We relate to the fellow-members of our communities: to our relatives, friends and others on the basis of various extents of love. Our relatives receive goods and services from us as presents and not on a commercial basis, and this has far-reaching consequences. The basis of economy and the society is the family. It is important to look at our children as human capital, as investment that returns when we grow old. Money should serve society and not the other way round. Religious background is equally important for democracy and free-market economy, also in the modern times.

Journal of Economic Literature (JEL) codes: H55, B1, E5, Y3

Keywords: history of economic theory, goods and presents, family-basis economy, faith and economy

\section{BEVEZETÉS}

A közgazdaságtan megváltása ambiciózus mú. ${ }^{1}$ Szerzője, John D. Mueller nem kevesebbet túz célul maga elé, mint a közgazdaságtan megreformálását. Egyrészt felülvizsgálja a smithi ihletésú szabadpiaci közgazdaságtant, másrészt modellt ad egy családgazdaságon alapuló társadalom- és gazdaságszervezôdésre.

Adam Smith fố múve, A nemzetek gazdagsága, melynek megjelenésétôl számítjuk a modern közgazdaság-tudomány kezdetét, a termeléssel és cserével foglalkozik. Ekkor szakad ki a közgazdaságtan mint tudomány a morálfilozófiából. Mueller a könyvében bemutatja, hogy Smith elôtt is voltak - méghozzá igen értékes - gazdasági gondolkodók. Három jelentôs forrásra utal, Arisztotelészre, Szent Ágostonra és Aquinói Szent Tamásra, akik a termelés és a forgalom mellett a fogyasztókkal és a végsó elosztás kérdéseivel is foglalkoztak. A neokonzervatív gazdaságelmélet (Jevons, Walras, Menger) késóbb e négy fogalomból beemelte a tudományba a szükségleteket, de a végsố elosztás kérdésével ezek a közgazdák is adósok maradtak.

E kérdésekre nem lehet egyszerúen válaszolni, ha a végsố elosztás nélkülözi az igazságosságot. Ami viszont már morális kategória, ezzel azonban visszakanyarodnánk a morálfilozófiához, amelytôl - önálló tudományként - a smithi közgazdaságtan éppen hogy elkülönülni szándékozott, és amelyrôl a mainstream közgazdaságtan azóta sem akar hallani.

Mueller sajátos fogalmat vezet be: szeretet-gazdaságtanról beszél. Úgy véli, a közgazdaságtannak a termelésre és a forgalomra vonatkozó nézetei figyelmen kívül hagyják, hogy végsố soron a gazdasági döntések konkrét személyek szükségleteirôl szólnak. 
A gazdasági cselekmények csupán eszközei a szükségletkielégítésnek. A termelés célja mindig az ember.

A személyekkel kapcsolatos érzelmi viszonyunk azonban különbözô. Nem egyformán szeretjük embertársainkat: a hozzánk közel állókat jobban, a tôlünk távolabbi embereket kevésbé, legalábbis ami a róluk való gondoskodásban megjelenik. A szeretetnek ugyanis két megjelenési formája van: a benevolencia és a beneficencia. A gyakorlatias kérdésekkel foglalkozó középkori tudósok, így Aquinói Szent Tamás is, úgy értelmezték az evangéliumi útmutatásokat, hogy nem kötelezó valakinek azért tönkremennie, hogy másokon segítsen. Bár kétségtelenül azt mondja az evangélium, hogy a legnagyobb szeretet, ha mindent szétosztasz, és követed a Mestert... De az irgalmas szamaritánus is csak vagyonának egy kis részével segítette a bajba jutott embert. Egy kereszténynek az Újszövetség szerint mindenkit úgy kell szeretnie, mint önmagát. Ez azonban nem jelenti azt, hogy mindenkinek ugyanannyit is kell adnia abból, amije van. Hiszen az eróforrások végesek, és ez döntô érv: elóbb jön tehát a saját családunk, aztán a többi ember. Szívból kívánom nekik, amit magamnak (benevolencia), és anynyit adok, amennyit tudok (beneficencia) (Mueller, 2015:843). Hiszen a személyek hozzám viszonyított helyzete különböző: a családtagjaimnak, barátaimnak ajándékba adok abból, amim van, másokkal azonban cserélek, azaz üzletelek. Hogy erôforrásaim végleg ki ne merüljenek!

A mainstream közgazdaságtan nem értelmezi az ajándékot mint gazdálkodási alapfogalmat, csak a cserét, az üzletet ismeri (Do ut des. Adok, hogy adj). Sót mi több, a mainstream még a családi kapcsolatokba is be akarja hozni az üzletelést! Mueller szerint azonban - és ezzel sokan egyetértenek - ez hibás felfogás, szerinte ugyanis a „családi gazdálkodás” jelentős részben ajándékozáson és nem cserén alapul. (S legyünk ószinték: nem nehéz ezt alátámasztani, ha egy beteg gyermekével önfeláldozóan törôdô anya vagy apa példáját tekintetjük; hol itt az üzlet?)

Mueller rendszerében - szemben a modern liberális felfogással, amely az egyénen alapul - a nemzetgazdaság elemei a családok, hiszen magának a munkának mint termelési tényezônek az „újratermelése” a családban történik. Ha tetszik, a gyermek e termelési processzus „eredménye”, a legfontosabb „termék”, akit vállaltunk, nevelünk és taníttatunk. (A könyv egyik fejezetének címe „csecsemóipar”, angolul „infant industry”. Valójában itt egy angol szójátékkal találkozunk, az infant industry ugyanis angolul a támogatandó új iparágakat jelenti. Szó szerint viszont „gyerekgyártás”, amelynek keretét viszont a családok adják. Természetesen abszurdnak hangzik ez a szóhasználat, de valóban életfontosságú gazdasági kérdés a gyermekek vállalása - vagy éppen nem vállalása.)

A szerzó bizonyítja, hogy a leghatékonyabb beruházás az emberi tőkébe való befektetés. Ennek hozama mindenképpen meghaladja a reáltókékbe való befektetésekét. Ugyanakkor az emberi élet véges: minél hamarabb épül bele a képzés eredménye az egyén „humán tôkéjébe”, annál tovább tudja azt kamatoztatni. De nem végtelenül: egy darabig ugyanis nô a humán tôke hozama, nyugdíjaskorban azonban hanyatlik, és a halállal elenyészik. Az emberi tôkénél éppen ezért nagyon fontos a pótlás, a gyermekvállalás. 
A könyv szerzôje e témakörben fontos társadalompolitikai, humánetikai problémát hoz elô: az abortuszt, vagyis a gyermek vállalásának legdurvább elutasítását. (Talán meglepó e téma felvetése a gazdaságtan alapjainak tárgyalásánál...) Kétségtelen, hogy a családgazdaságnak - egyben a társadalom fennmaradásának - döntô eleme a gyermek. Gyermek nélkül nincs társadalom sem, elóbb vagy utóbb, de biztosan felszámolódik. Az abortusz pedig a gyermek elvetését jelenti (Mueller, 2015:224).

A család Muellernél férfinak és nônek a gyermek világra jöttét is lehetôvé tevô szövetsége, amelynek legcélszerúbb formája a házasság. E téma kapcsán érdekes dolgot elemzett: vajon van-e szerepe, és ha igen, mi, a házasságok tapasztalható csökkenésében a legalizált abortusz létének? A kérdésfeltevés valójában meglepô, az abortusz legalizálásának szószólói nyilvánvalóan nem ilyen összefüggésben gondolkodtak a lépés helyességérôl. Azt gondolták, hogy a - régies kifejezéssel - „megesett nônek” nem kell megszülnie a gyermeket, ha a gyermek apja nem akarja elvenni ôt feleségül, így kevesebb lesz a házasságon kívül született gyermek. Mégsem így történt, ellenkezôleg, nagymértékben nôtt a házasságon kívül születettek száma, sokan ugyanis megtartják a gyermeket akkor is, ha nem házasodnak össze, még akkor is, ha volna mód rá, hogy elvetessék. Csak éppen nem tartós kapcsolatban, esetleg társ nélkül nevelik fel a gyermeküket (ami persze a gyermeknek nem feltétlenül ideális). Emellett nô a házasságok felbomlásának száma is. A szétesett vagy létre sem jött házasságokban nevelôdô gyermekek helyzete közismerten nehezebb, mint a teljes családban felnövôké. De mi köze ennek az abortuszhoz? Mueller érdekes összefüggésre hívja fel a figyelmet.

Ha az anyák fenntartják a jogot, hogy az abortuszról - gyermekeik életéról és haláláról - kizárólag maguk döntsenek, „az én testem az én testem” hangoztatásával, akkor a férfiak is fenntartják, hogy ôk is egyedül döntsenek a saját életükról, lerázván így a gyereknevelés gondját, mondván, a gyermeket nem ók, csak az aszszony akarta megtartani (Mueller, 2015:220). A férfi csupán a gyerektartást fizeti, ha ugyan fizeti. Az emancipációért és ezen belül az abortusz jogáért küzdô feministák tehát elérték azt, hogy a társadalomban a gyermeküket egyedül neveló anyák életszínvonala sokkal alacsonyabb lesz, mint a házasságban élố társaiké. ${ }^{2}$ Végsố soron a nagy individualizmussal az egész társadalom átlag-életszínvonala alacsonyabbá vált azáltal, hogy nem kötelezôdünk el, nem vállalunk a családért alkalmazkodást és áldozatot. Felemás gyôzelem ez, mellyel sikerült elérni, a társadalmi haladás eredményeként, hogy rosszabbul éljünk.

Az abortusz napjainkra bevett gyakorlattá vált, és nem gondolunk bele, hogy valójában mit is jelent: egy élet elvételét. Egy másik, igencsak megdöbbentô és kissé abszurd elemzéssel Mueller bemutatja, hogy az USA-ban a búnelkövetôk jelentôs része - méghozzá jellemzốn az élet elleni cselekmények elkövetôi - az abortuszokban „tettestárs” apákból kerül ki. (Amerikában mindenre találunk statisztikát és felmérést, több évtizedre visszamenô idôsorok alapján, így a sztochasztikus kapcsolat kimutatható.) Mueller következtetése, hogy ugyan miért ne ölne meg más embert is az, aki a saját vérének elpusztításában egyetértô félként vesz részt (Mueller, 2015:182)? 


\section{CSALÁDALAPÚ GAZDASÁg ÉS TÁRSADALOM}

Mueller - véleményem szerint helyesen - úgy tekinti a családot, mint a társadalom alapsejtjét, melyben a két fél egyfajta munkamegosztást alakít ki. Nagyon fontos a családban a nem pénzért végzett munka is. Talán kissé konzervatívnak túnhet, amikor a szerzó a családanyai, a „csak” háziasszonyi hivatást ilyen magasra értékeli. Ezzel azonban messze nem retrográd, hanem kifejezetten progresszív véleményt fogalmaz meg! Nem lekezeli, hanem felmagasztalja a háziasszonyokat. Chestertonra, a nagy keresztény gondolkodóra hivatkozik, amikor azt mondja, hogy Mrs. Jonest lehet sajnálni feladata nagysága, de nem kicsinysége miatt... Hiszen, egy gyermeknek nem valamit kell megtanítani, hanem mindent. Az anya, aki ennek szenteli az életét, a legnagyobbat teszi, amit tehet. Úgy fogalmaz, hogy a háziasszony, az anya, szeretettel ajándékozza munkáját és idejét a családja tagjainak, olyan szolgáltatásokat nyújtva, amelyekért a piacon sokat kellene fizetni. Így hozzájárulása a család jólétéhez igen jelentôs. (Figyeljünk az ajándékozás kifejezésre!)

Itt érdemes elgondolkodni azon, hogy a technikai haladás valóban jelentôs mértékben fölöslegessé teszi majd az emberi munkát az elkövetkezô évtizedekben. Ennek következtében a munkaerô egy részére a termelési folyamatban nem lesz igény. Mesterségesen kell majd „munkahelyeket” teremteni, hogy jövedelemhez juthassanak az emberek. (Hacsak nem kívánunk alapjövedelmet juttatni mindenkinek.) Ezért nagyon fontos lenne, hogy a munkaerôpiacról önként távol maradó nôk számára valós opció legyen a gyermeknevelés, gyakorlatilag a családi gazdálkodás vezetése, noha tény, hogy sok áru és szolgáltatás megvásárolható a piacon (manapság gyakorlatilag minden), így semmiképpen nem kell mindazt otthon elvégezni, ami korábban „hagyományos” női munka volt. Ezért megfontolandó, hogy valaki kizárólagosan erre az életformára rendezkedjen be. Mivel telhetne normális körülmények között egy háziasszony élete, ha van elegendó jövedelme a szolgáltatások piacról való megvásárlására? Feladat nélkül maradna, bizonyos értelemben. Ezzel azonban Mueller nem foglalkozik.

Chesterton idézett mondatára utalva, el kell gondolkodnunk, hogy milyennek kellene lennie a fóállású feleségnek, anyának. A chestertoni elvárás, hogy „mindenre” meg tudja tanítani a gyermekét, azt igényli, hogy ó maga is magasan képzett legyen. Manapság úgy gondolják, hogy a magas szintú képzésben részesült nôk elvesztegetik a taníttatásukba beleölt pénzt, ha otthon maradnak, holott csakis egy magasan képzett személy képes minôségi humán tôkét képviselô személyt nevelni a gyerekeiből. Ahhoz, hogy helyes irányba tudjuk ösztönözni a gyerekek fejlódését, nem árt, ha az általa tanult tárgyakhoz értünk is valamit. (Csak halkan jegyzem meg, hogy Heller Farkas, a híres magyar közgazdász olyan családban nôtt fel, ahol az édesapa akadémikus volt. Az édesanya magasan múvelt asszonyként, életét három fia nevelésének szentelte, akik közül kettố ugyancsak akadémikus lett.) Fontos, hogy a szülő maga is lépést tartson a korral, tudjon a mai gyermekek „nyelvén beszélni”. Legfőképpen az általános múveltség körébe tartozó ismeretek szélesítése szükséges. Nem arra kell gondolni, hogy megcsináljuk helyette a leckét, de arra igen, hogy a hatalmas információhalmazban való eligazodást segítsük. Jó esetben mégiscsak közelebbrôl ismerjük gyermekünk 
érdeklődési körét, hajlamait. Tereljük, gazdagítsuk, egészítsük ki játékosan a kötelezô oktatási anyagot, töltsük meg élettel a tankönyvi példákat! Nem feltétlenül az a helyes megoldás, hogy a gyermekek legyenek kötelezóen reggeltól estig a közösségi intézményekben, inkább az, hogy az iskola utáni idôt a szülók oszthassák be számukra. Egyébként az oktatási rendszerben feltétlenül lennie kell a családi életre nevelést segítô tárgyaknak is, különbözô életszakaszokban, hogy felkészülhessenek a fiatalok, leendô anyák és apák, erre a nagyszerú hivatásra. Az élet egyszerú dolgaihoz nem kell rendkívüli tudás, a különbözó helyzetek kezeléséhez azonban szükségesek megfelelő készségek.

Az életre neveléshez fontos, hogy a gyermeket engedjük az élet közelébe kerülni, annak érdekében, hogy magából az életbôl tanuljon. Legyen idônk vele fôzốcskézni, szerelni, otthonunkban vagy a szabadban együtt dolgozni; megfigyelni és közösen megtapasztalni az életet. Persze, ha képesek erre a szülők, és ha kellő idôt otthon tudnak lenni. A mai szétesett családokban ezzel aligha lehet számolni, hiszen a megélhetéshez (és mint láttuk, a rosszabb megélhetéshez) jelentôs munkamennyiséget kell ledolgoznia a magára maradt szülőnek, így örül, ha a gyermeke felügyelet alatt van. Ami sokszor nem is a rosszabbik megoldás, tekintve, hogy sok szülő nem lenne feltétlenül jó nevelôje a felkészültsége, példaadása okán sem. Ezen a problémán csak a társadalom oktatási és morális színvonalának emelkedése segíthetne. Ez pedig a „róka fogta csuka” esete: éppen a jelen kor munkakényszere teszi lehetetlenné, hogy a leendô szülô kellô ideig, majd késôbb folyamatosan képezhesse magát, hogy önmúvelésére kelló idó jusson. Ha valakinek egyedülálló szülóként egyszerre kell helyt állnia a munkahelyén és otthon is, akkor sem ideje, sem ereje nem marad az önmúvelésre. De ami még nagyobb baj: a gyerekre sem. Felmerül a kérdés: ezt akarták az emancipáció hirdetôi?

Mielótt az a vád érne, hogy Mueller gondolatait elemezve holmi antifeminista nézeteket népszerúsítek, hangsúlyozom: az emancipáció szükséges! Sok nố egyedül kénytelen megállni a lábán, és ezt kiválóan képes is megtenni. Ugyanakkor fontos, hogy a párkapcsolatban élóknek is legyen lehetôsége választani: legyen módja munkát vállalni, de legyen lehetôsége arra is, hogy az otthoni munkát választhassa. Ez túlzott kívánságnak hangozhat egy olyan gazdasági rendszerben, amely gyakorlatilag a két fizetésból fenntartható otthonra van „kalibrálva”. Az ilyen megoldásokhoz mindenekeloott az szükséges, hogy a pár tartós kapcsolatban, jó esetben házasságban éljen, amelyben a családtagok együttes jövedelme elegendő a megélhetéshez, még akkor is, ha a nô hosszabb-rövidebb ideig otthon marad. Mindenképpen fontos, hogy a házasság olyan életre szóló szerzódéses viszonyt jelentsen, amelyben a felek teljesen egyenjogúak, függetlenül attól, hogy valaki pénzzel vagy munkával járul hozzá a család jólétéhez. Az otthoni munka felértékelôdése elengedhetetlen feltétele a családalapú társadalomnak, ugyanakkor fontos, hogy ez ne jelentse a nók lehetôségeinek életre szóló determinálását. Mueller rámutat: a társadalom kötelessége, hogy az életpályák folyamatában részmunkaidôs foglalkozással, továbbképzéssel az „üres fészek” korszakába érkezô nôk számára a társadalomba való visszaintegrálódást segítsék. Semmiképpen nem szabad az értékes embereket parlagon hagyni egész életük folyamán, még ha ebból számos évet, évtizedet a saját gyermekeikre szántak is. 
Véleményem szerint különleges fontossága van annak, hogy a szülők saját gyermekeik családalapításánál nagyszülóként segíteni tudjanak. Ezt azonban meggátolja, ha mindenkinek, gyermekeseknek és gyermekteleneknek, nóknek és férfiaknak egységesen kitoljuk a nyugdíjba menetelét. Ennek következménye lesz, hogy a fiatal generáció is kitolja, halasztani fogja a gyermekvállalást, ahogyan ezt már manapság is tapasztalhatjuk. Hiszen gyermek mellett, segítség nélkül, ha nincsenek nagyanyák (esetleg nagyapák), akik szükség esetén ott tudnak lenni a gyerekek körül, igen nehezen tudnak dolgozni. Mindez a kérdéskör igen bonyolult, összefügg többek között a társadalmi mobilitással, a munkalehetôségek és a lakáskörülmények alakulásával, de a szociológiai, pszichológiai, erkölcsi kérdések legalább ilyen súlyúak. ${ }^{3}$

Nem könnyú tehát kijelenteni, hogy vissza kell térni a családalapú gazdaságszemlélethez, ehhez nagyon sok mindennek kell fokozatosan megváltoznia. Bár akadhatnának rásegítố mechanizmusok, az egyik ilyen lenne a nyugdíjrendszer reformja.

\section{NYUGDÍJRENDSZEREK}

Mueller könyvének jelentôs hányada foglalkozik a demográfiai problémák és a nyugdíj összefüggésével. Azok számára, akik Magyarországon ezzel a kérdéssel évtizedek óta foglalkoznak, megnyugtató látni, hogy jó úton járunk. Az amerikai közgazdász is hasonlóan fogalmaz, mint Demény Pál, Botos József, Szegó Szilvia vagy a jelen tanulmány szerzôje. Nemcsak Mueller látja ezt így: számos jeles demográfus és nyugdíjszakértố mutatott rá külföldön is a megdöbbentó tényre: a nyugdíjrendszer gyakorlatilag gyermekellenes társadalmat hozott létre. Talán túl erôs ez a megfogalmazás; mondjuk inkább úgy: a gyermekvállalás iránt közömbös társadalom jött létre.

Hiszen ma már nincs szükség arra, hogy valaki felvállalja a gyermeknevelés nehézségeit. Ha rendesen fizeti a nyugdíjjárulékot, gyerek nélkül is meglesz a megélhetése idôs korában. Legalábbis az emberek jó része így gondolja. Mindez, egybevetve a napjainkban tapasztalható csekély elkötelezôdési hajlammal, végtelenül lenyomja a születésszámokat. Az egyiknek azért nincs gyermeke, mert párt nem talál hozzá, másoknál biológiai okokból nem lehet, megint mások kényelmi szempontból nem vállalják. Ez azonban a társadalom halála.

Mivel napjainkra a demográfiai robbanás már a határához sodorta a Föld teherbíró képességét, sokan azt mondják, jól is van ez így. Szögezzük le: a népességrobbanás megállítása valóban sorskérdés. Csakhogy a túlnépesedés nem a nyugati civilizáció országait jellemzi. A nyugati civilizáció eltúnéséért, amely a jelenlegi alacsony gyermekvállalási számok mellett minden bizonnyal reális jövőkép, nem feltétlenül kárpótol más civilizációk elterjedése. Az európai gyökerú civilizáció „kihalásáért”, amely olyan hatalmas eredményeket teremtett az emberiség számára, mégiscsak nagy kár lenne!

Mit javasol Mueller ennek a kérdésnek a megoldására? Meglepó módon - noha a konzervatív politikai oldal szakértő közgazdásza -, nem a nyugdíjkérdés piaci megoldásainak szószólója. Épp ellenkezóleg: rámutat arra, hogy az amerikai modell, az elôtakarékosságon alapuló tôkefedezetû nyugdíjalapok rendkívül sebezhetôek. Jobbnak tartja a felosztó-kirovó rendszereket, amelyek az állam garanciáját nyújtják, és nin- 
csenek kitéve a befektetési értékpapírok áringadozásának. A befektetési lehetôségek hozama egyébként jelentôsen alatta marad a humán tôkébe történô beruházások hozamának. Az amerikai viszonyok közepette a béradókból finanszírozott társadalombiztosítási nyugdíjrendszer (Mueller könyve írásának idején) többletet produkált, amit a költségvetés más célokra elköltött. Erre a többletre a jövóben nem lehet számítani, hiszen a demográfia alakulása miatt lényegesen több lesz a járadékigény, mint a befolyó befizetések. (Nálunk is hasonló a helyzet, mint Amerikában. Ma még nem finanszírozhatatlan a nyugellátás, 2030-ig nem is aggódik a kormányzat a tb egyensúlya miatt. De hogy mi történik majd a demográfiai apály következtében, az már most jól látható.)

Mueller azt látja követendô útnak, hogy csökkentsék a járulékokat, a „béradókat”. Ezzel eltúnne az aktuális társadalombiztosítási többlet, ugyanakkor több maradna a családok költségvetésében, amit a legfontosabb befektetésre: gyermekeik tanittatására fordíthatnának. A tervek szerint majd a juttatásokat is visszafognák, így az egyensúly késóbb sem borulna fel. A tanult gyermekek munkája ugyanis jobb béreket, több adófizetést jelentene a jövôben.

Ez a javaslat valószínúleg kevéssé lenne átvehetô egy az egyben az Újvilágból, egy „lába” a javaslatnak - a szochóvá alakított járulék mérséklése, melyet a vállalkozások fizetnek - azonban már valósággá vált gazdaságunkban, egyértelmúen vállalkozásösztönzési céllal. Ez azonban a Mueller által felvázolttól eltérôen nem az emberek zsebében jelent több pénzt, hanem a vállalkozásoknál enyhíti az adóterheket, igaz, bizonyos mértékig lehetôvé teszi a bérek emelését is. (Az európai nyugdíjmodell eltér az amerikaitól. Az öreg kontinensen a felosztó-kirovó rendszereknél a munkáltató és munkavállaló között megosztva jelentkezó járulékfizetés a gyakorlat.) Noha azt helyesnek tarthatjuk, hogy Mueller a felosztó-kirovó rendszert pozitívan értékeli, a hazai átlagos jövedelmi viszonyok mellett a juttatások mérséklése nálunk mégsem lenne elfogadható. Sokkal fontosabb lenne egy olyan reform, amely az otthon végzett munka értékeléseképpen nyugdíjat biztosítana a gyerekeket nevelő, taníttató szülôknek. Hiszen éppen ezek a gyerekek lesznek azok a munkavállalók, akik megtermelik majd a jövóbeni jövedelmeket, és fizetnek abból adót, járulékot a költségvetésbe, amiból aztán szülőik generációja a nyugdíjat megkaphatja. (Az otthon végzett munkát, mint láttuk, Mueller is magasra értékeli, tehát ezt a juttatást sem „munka nélkül” kapnák az emberek; ók életük során természetben „fizettek” járulékot.) Szerzônk nagyon világosan látja, hogy a következô generáció vállalása, felnevelése sorskérdés, úgy Európában, mint Amerikában. Mint írja, nem lehet a „gólyaelmélet” alapján állni (Mueller, 2015:288). Az egyéni számlás elôtakarékossági rendszerek kigondolói ezt teszik, hiszen nem gondolnak arra, hogy a most munkát vállalókat sem a gólya pottyantotta munkavállalásra készen a munkaerópiacra, hosszú „befektetési folyamat” eredményei.

Napjainkban sokan ezt a kérdést a migrációval óhajtják megoldani. „Készen venni” meglett, felnôtt férfiakat, gazdasági bevándorlókat. Ennek a jelenségnek a kulturális-szociális vonatkozásait, buktatóit, sajnálatos módon, az érdekelt körök nem veszik figyelembe. Egyrészt megváltoztathatatlan adottságnak tekintik a népességfogyást, mintha arra nem lehetne semmilyen módon hatni. Pedig az északi államok gyakorlata Európában sok pozitív eredményt mutatott fel, az állam által finanszírozott adekvát 
szociális politikák hatására. Másrészt a migráció pártolóit korántsem zavarja az esetleges munkaerô-túlkínálat, amely bizonyos béreket lenyomna, sốt, nyilvánvalóan örömmel fogadnák ezt.

Manapság még nagy országok sem engedhetik meg maguknak, hogy olyan közgazdasági modellekben gondolkodjanak, amelyek nincsenek tekintettel a globális jelenségekre. Globálisan van túlnépesedés, míg másutt népességcsökkenés várható. De egészen bizonyos, hogy nem az a megoldás, hogy utat nyitunk a korlátlan migrációnak. Az egyes gazdaságok polgárai ugyanis védeni szeretnék elért eredményeiket: ôk fektettek bele, az ô munkájuk gyümölcse. Hajlandók ugyan áldozatokra a rászoruló menekültek felé, különösen humanitárius katasztrófák esetén, de nem biztos, hogy munkáltatóik gazdasági érdekeiért (olcsóbb munkaerô) könnyedén feladnák integritásukat, kultúrájukat, amit a más kultúrkörból érkezô bevándorlók tömeges befogadása minden bizonnyal jelentene. Különösen, ha ez anyagi helyzetük jelentős romlásával járna. Felvetôdik akkor a kérdés: vajon kinek az érdekeit szolgálja a gazdasági migráció? A lokális gazdasági viszonyokban való gondolkodás egyre gyakoribb a progresszív társadalomtudósok körében. Szükséges, hogy erre a politikai és gazdasági hatalom birtokosai is kellően odafigyeljenek. A helyi társadalmak érdekeinek védelme jogos igény.

\section{A PÉNZÜGYI RENDSZER}

Az amerikai pénzügyi rendszer elemzésekor Mueller azok sorát gyarapítja, akik a pénz aranyalapra helyezését kívánatosnak tartják. Véleménye szerint amire szükség van: „Korszerúsített aranypénzrendszer, valutatartalékok nélkül” (Mueller, 2015:342). Hivatkozik arra, hogy a fóbb valuták aranyra való átválthatósága (1879-1914) idején mutatkozott az amerikai történelem legjobb teljesítménye az árstabilitás tekintetében. Leegyszerúsített azonban ezen eredmény egyetlen faktorra való visszavezetése, hiszen az aranypénzrendszer múködését reálgazdasági és állampénzügyi, jogi-szabályozási tényezôk sokasága tette lehetôvé, amelyek hallatlanul versenyképessé tették az amerikai gazdaságot. Inkább okozat volt tehát az aranyvalutarendszer léte, mint ok. Egyáltalán nem meggyôzố érv, hogy ma is nagy mennyiségú aranykészlet van a monetáris hatóságok birtokában, hiszen annak eloszlása meglehetôsen szórt. Márpedig éppen az vezetett az elsố világháború után a nemzetközi kereskedelem leállásához, hogy Amerika reálgazdasági fölénye miatt szinte minden aranykészlet az USA-ba áramlott, így az aranyalapú nemzetközi pénzrendszer, a konvertibilitás a Nagy Válság idején megbukott.

Mueller a pénzelméleti kérdésekkel foglalkozva megkülönbözteti a nagy erejú és a kis erejú pénzeket, vagyis a jegybankpénzt és a kereskedelmi banki pénzt. Az utóbbi szerinte nem is pénz. Úgy fogalmaz: a nagy erejú pénz tartalékolása biztosítja, hogy a bankok ennek arányában bóvítsék vagy szúkítsék hitelezésüket, vagyis a tartalékelhelyezés révén lévô pénzmultiplikálás elmélete alapján áll. A közgazdászok pongyola fogalomhasználatának nevezi, hogy a kereskedelmi bankok hitelnyújtását is pénzteremtésnek nevezik (Mueller, 2015:328), pontosabban, hogy a kétfajta pénzt a fenti módon különböztetik meg. A problémát abban látja, hogy a szuperpénznek, a nagy erejú pénznek, vagyis a jegybanki pénzteremtésnek nincs valamifajta horgonya, és így az árszintek 
alakulásának sincs. De milyen árszintekrôl is van szó? Hiszen a modern hitelteremtés messze nemcsak árukra és szolgáltatásokra irányuló keresletet teremt, hanem pénzügyi aktívákra is. Ezt, vagyis az eszközárak alakulását például nem vették számításba az inflációnál. Pedig a modern banki finanszírozásban - szerintünk pénzteremtésben az értékpapírokra irányuló kereslet, illetve a jelzáloggal fedezett ingatlanhitelek teszik ki a banki tevékenység aktív oldalának nagyobb részét (Turner, 2015).

Ha megnézzük a Bank of England kiadványait, vagy éppen a Deutsche Bundesbank friss pénzügyi tantananyagait (Naser, 2018), világosan látszik, hogy a kereskedelmi bankok éppen úgy teremtenek fizetôeszközt könyveikben, mint a jegybank, egyidejûleg megemelve mérlegük aktív és passzív oldalát. Amíg egyébként a jegybank által teremtett pénz a bank ügyfélkörén belül kerül felhasználásra számlajóváírások útján, nincs gond. A banki klíringek egyenlegét azonban kétségkívül jegybankpénzzel kell rendezni. Amennyiben felmerül, hogy az ügyfél készpénzt kér, a bank rendelkezésre bocsátja a pénztárállományából, vagy a jegybanknál csökkenti tartalékait, esetleg refinanszírozást kér. Mégis, állíthatjuk, hogy a kereskedelmi bankok pénzteremtése nem függvénye a náluk elhelyezett betéteknek, azaz, a bankok nem puszta pénzközvetítók, ahogyan ezt Mueller írja. Szerezhetnek pénzt más kereskedelmi bankoktól is a bankközi piacon (kamat fejében). A jegybank (ECB) pedig mindenképpen utánamegy a kereskedelmi bankok jegybankpénzigényének, ha a bankközi elszámolásokban szükség lenne rá. Ez mehet a jegybanki tartalékokból, de a kereskedelmi bank szerezhet pótlólagos refinanszírozást az ECB refinanszírozási akcióiban való részvétellel is, biztosítékok ellenében. De napi hitelt is kaphat, ilyenkor természetesen magasabb kamatért. A lényeg: a kereskedelmi bankok bizony pénzt teremtenek; fizetôeszközt, amely befolyásolja az áruvilág iránti keresletet, így az inflációt. A kereskedelmi bankok pénzteremtése azonban nem korlátlan, hiszen függ a reálgazdaság igényeitôl, a hitelfelvevôktốl, a banki szabályozóktól. De nem a jegybanki szándékoktól. A jegybanki ráhatás lehetôsége korlátozott.

Az USA esetében a belsố pénzügyi rendszer és a nemzetközi pénzügyi rendszer szoros egységet alkot, hiszen a dollár az egész világ számára kulcsvaluta. Amerikaiként nem lehet a két kérdést egymástól elszakítva tárgyalni. Mueller helyesen mutatja be, hogy a dollár tartalékvalutaként való alkalmazása nemcsak lehetôvé, de szükségszerưvé is teszi, hogy az Egyesült Államoknak fizetésimérleg-hiánya legyen a külfölddel szemben (Mueller, 2015:330). Világosan és egyértelmúen igazolja, hogy az Egyesült Államok krónikus fizetésimérleg-hiányát nem a fogyasztók túlköltekezése, hanem a költségvetés elszaladása okozza, párosulva a dollár tartalékvaluta-szerepével. Utóbbi teszi lehetôvé ennek a hiánynak a nemzetközi finanszírozását (erre a kérdésre Triffin már a hatvanas évek elején rámutatott, amikor felvetette a nemzetközi pénzügyi rendszer reformját, és egy kreált nemzetközi tartalékvaluta, az SDR létrehozását szorgalmazta) (lásd Botos, 1983).

Napjainkban sokan hivatkoznak az aranypénzrendszerre. Mueller is, mint fentebb idéztük, ebben lát egyfajta megoldást. Hagelmayer István és tanítványai számára, akikkel együtt végiggondolták a hatvanas-hetvenes években az aranydeviza-rendszer tündöklését és bukását, nehezen hihetô, hogy ez jó ötlet lenne (Hagelmayer et al., 1975). 
(Persze, Mueller elgondolásában valószínúleg szerepet játszik, hogy Amerika az aranykészletekben gazdag, aranytermelésében már a 2000-es évek elején utolérte Dél-Afrikát.) De nem vethetjük el a témát egy puszta kézlegyintéssel, napjainkban is vannak ugyanis, akik ezt a gondolatot napirenden tartják. 2012-ben például a Chatham House (Royal Institute of International Affairs) szakértôi csapata átfogóan tanulmányozta az arany- és a nemzetközi pénzügyi rendszer kérdését. Trump elnök tanácsadói körében több ilyen szakértố is akad. Noha e lépés bekövetkezését nem tarthatjuk valószínúnek, a dollár kulcsvalutaszerepének csökkenésére mindenképpen számítani lehet.

\section{ZÁRÓ GONDOLATOK}

Mueller a könyvét gyakorlatilag azokkal a világnézete által meghatározott gondolatokkal fejezi be, amelyekkel elkezdte. Rámutat a különbözó filozófiai hátterú közgazdasági iskolákra, amelyek mögött véleménye szerint mindig valamiféle vallási világkép húzódik meg. „A piaci rend minden elmélete nyilvánvalóan teológiai” (Mueller, 2015:353). A legfontosabb kérdés, írja a magyar származású Jáki Szaniszlóra, a Templeton-díjas ${ }^{4}$ tudománytörténészre hivatkozva, hogy elfogadjuk-e a világ teremtettségének a tényét. Jáki szerint ugyanis csak ennek alapján lehet egzakt tudományos kutatást végezni. Erre alapozva Mueller úgy véli, hogy az emberi viselkedés gazdasági megközelítésével foglalkozó, modern közgazdászok elkerülhetetlenül „neoskolasztikusokká” válnak majd. A modern közgazdászoknak újra kell tanulniuk az Adam Smith elôtti közgazdasági gondolatokat. Fontos következtetése, hogy elkerülhetetlen az elmélettörténet visszaállítása a közgazdászképzésbe, amit az elmúlt évtizedek egyszerúen „kifelejtettek" belóle.

Érdekes logikai okfejtéssel kapcsolja össze az amerikai demokrácia alapelveit a szabad döntéseket feltételezô közgazdaság elméletével, amelyben az is egy opció, hogy ajándékot adunk. „Csak akkor vagyunk képesek szabadon dönteni az általunk kedvezményezni kívánt személyekre vonatkozó gazdasági cselekedeteinkben, ha egyenlônek teremtettünk; és csak úgy lehetünk egyenloonek teremtve, ha eleve teremtmények vagyunk..." (Mueller, 2015:356; kiemelés - B. K.)

\section{JEGYZETEK}

1 Recenziót olvashatnak a könyvrôl a Közgazdasági Szemle 2017. októberi számában, Halm Tamástól. E tanulmány célja a szerzố nézeteinek kritikai elemzése.

2 Adott esetben az apáké is, akárcsak magányos öreg szingliké, egyedül élô vagy özvegy nyugdíjasoké, vagyis azoké, akik nem támaszkodnak a tágabb családra. Ez ugyan nem szorosan a témához tartozik, de valamelyest mégis ide kapcsolódik. Angliában ugyanis kimutatták, hogy az egyedül élô nyugdíjasok életszínvonala lényegesen rosszabb, mint a nagycsaládban élő öregeké.

3 A lakhatással egyébként ismét egy olyan kérdéshez érkeztünk, ahol mintha a társadalmi haladás visszájára fordult volna. A régi idôkben, amikor a megélhetés térben jobban eloszló volt - már csak a földmúvelés térhez kötöttsége miatt is -, a fiatalok lakáskörülményei racionálisan úgy oldódtak meg, hogy a fiatal párnak a portákon a nagy ház mellé építettek egy kis házat. Ha ma valaki a vidéket járja, és olyan falurészletekhez ér, amelyek még a szocializmus elôtt épültek, az ország minden táján látni fogja a „kis ház, nagy ház” portaelrendezéseket. Ez a takarékos megoldás biztosította, hogy a generációk egymás 


\section{Botos Katalin: Egy pénzügyes közgazda gondolatai A közgazdaságtan megváltásáról}

mellett tudjanak élni, nagyobb súrlódások nélkül. Sôt, amikor fordult a kocka, és az idôs emberek már nem bírták a gazdaságot, cseréltek: ốk költöztek a kis házba, a fiatalok meg a gyerekekkel a nagyba. Az iparosodás és a városokba költözés aztán anakronisztikussá tette ezt a modellt, egyre több fiatal ment a városba munkát keresni. Ma már egy korábbi ilyen generáció is a nyugdíj felé közeledik. A hazai viszonyokat tekintve, a napjainkra megfizethetetlen (fốvárosi) lakásárak a fiatalok számára szinte lehetetlenné teszik a (közös) városi lakásokból való elköltözést, ugyanakkor rengeteg vidéki ház áll üresen vagy kihasználatlanul. A lakáspolitikáért és a vidékfejlesztésért felelősöknek fel kellene arra figyelniük, hogy városi körülmények között kell megoldani a generációk tartós vagy ideiglenes együttélését lehetôvé tevô lakáskonstrukciók elterjesztését és a vidéken maradást a jelenleginél jobban támogató fejlesztéspolitikai elképzeléseket. Megfelelô munkalehetôség híján tovább fokozódik a városok elszívó ereje, tovább válik kihasználatlanná, elvesztegetett nemzeti vagyonná a vidéki lakásállomány. Társadalmi-szociológiai problémák tömegét okozza mindez. Sajnálatos módon a mai világban egymástól nagy távolságra élnek az elszakadt családtagok, vidéken magányra vannak ítélve az idősek, a városban kulcsosgyerek-létre a legfiatalabbak. Ez a jelenség nemcsak nálunk jelentkezik, de a sokkal nagyobb lakáspiaci mobilitással rendelkezô Amerikában is.

4 Sir John Templeton amerikai keresztény milliárdos, aki által létrehozott alapítvány a Nobel-díjnál is nagyobb összeget jelentô Templeton-díjat olyan, nemzetközi zsûri által kiválasztott személyeknek, illetve tudósoknak adja, akik a magas színvonalú munkájukat a nagyfokú spiritualitással társítják.

\section{FELHASZNÁLT IRODALOM}

Botos Katalin (1983): Pénz - nemzetközi pénz. KJK, Budapest.

Hagelmayer István - Bánfi Tamás - Boros Imre (1975): Az aranydeviza-rendszer kudarcai és tanulságai. Közgazdasági és Jogi Kiadó, Budapest.

McLeay, Michael et al. (2014): Money Creation in the Modern Economy. Bank of England Quarterly Bulletin, No. 1.

Mueller, John D. (2015): A közgazdaságtan megváltása. A hiányzó elem újrafelfedezése. MCC - Tihanyi Alapítvány, Budapest.

Naser, Rainer (2018): Wie kommt das Geld in die Welt? Wochenschau Verlag, Frankfurt am Main.

Turner, Adair (2015): Between Debt and the Devil. Princeton University Press, Princeton, https://doi.org/ $10.1515 / 9781400873326$. 